\title{
THE SORROW OF EGYPT
}

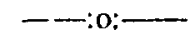

[Owing to lack of space this article has unfortunately had to be somewhat reduced. The life-stories given are in the words of the writer.-ED.].

To the tourist, the land of Fgypt is filled with the strange, haunting charm of the antique and with the tumultuous motion of its modern life, set in the wonderful colours of sun and sand. Picturesque women may be seen with their gracefully-poised waterpots climbing up from the riverside against a background of rich afterglow, and it. is casy to idealize existence and forget that behind the beauty there lies a social system fraught with sorrow and suffering for womanhood. In palaces of stone and hovels of mud lives are being starved out in living death, and those who know can only portray in part the utter sadness of the sorrow of Egypt. The general statement is here vacant of content, and in the cases which follow the writer has drawn from personal experience and selected only those which are typical of daily happenings. There is, perhaps, much to make those who argue on the advantageous position of woman under Islam ponder.

Perhaps the greatest horror of this " clarkness and valley of death" in which Egypt's women sit is the fear of divorce. It is this that causes loud lamentations and many Rachels weeping for their children.

Iittle Ikbal kept growing strangely shabbier, until a summons from the school brought a broken, wretched mother with a tale of how the father, a prosperous dragoman, had suddenly divorced her, leaving debt and poverty. In the same town, one that throngs with tourists, some of them captivated by the suavity of this very dragoman, Azeeze was divorced because her little boy was burned to death. "I should not have cared," said her husband, "if the child had been a girl "; but she wailed, "They blame me as if it were not harder for me than for anyone else." Nor had she sympathy from her father, who soon married her again, this time for five months, until the new hushand wanted to return to wife and children in Cairo.

Lateefa of B-, in her nineteenth year, has been divorced four times; Ibraheem Effendi, a youth of twenty-seven in this city, has been married thirteen times. Another youth, when reproved for taking a twenty-eighth wife, replied, "And why should I not, when my father divorced thirty-eight ?" A remonstrance against cruelty may only elicit the reply, "She is my wife. I have a right to beat her if I wish" ; or, more frankly, "It is a part of our religion. A woman is like $a$ pair of shoes. If she gets old a man throws her away, and buys another as long as he has money."

A prominent Moslem makes the statement that not more than five per cent. of Egyptian wives escape divorce. The Consul-General's report (1907) throws some light on the extent of this "sorrow": 


\section{THE SORROW OF EGYPT}

"During the past yenr, 176,474 certificates of Moslem marringes were delivered. There were 52,992 cases of divorce. In other words, for every seven wonien married there were rather more than two divorced. This is a large proportion." It is even larger if the remark of a police official is accepted: "They don't make any pretence of recording all divorces. You find a woman in this house to-day and in another to-morrow."

As regards polygamy, a Mohammedan, who is in a position to know, considered it as common among the poor as among the rich, except in the cities where extra wives are a burden. In the country the women can work. At least fifty per cent. of the Egyptians are still polygamists. In answer to the assertion that all this evil is in spite of and not an integral part of the religion of the land, there is abundant testimony from those who have studied the problem: "This legalized immorality which the law of Islam perinits and the cxample of Moliammed doubly sanctions, was introduced into the Nilo Valley by Moslem domination, and is to-day, by its degradation of womanhood, the most serious problem of missions as it is also the greatest barrier to progress." C. R. Wutson.

Then there is the sorrow of the child-wife, who has known no girlhood, and of the baby who has had no real mothering given to it. What can one expect of the children with heritage such as this ? There is much of truth as well as pathos in a fourteen year old mother's reply, who was laughingly asked how much she would want for her boy: "Oh, just give me a piaster and take him. He cries at night and keeps me awuke, and I don't know what to do with him !" Aly's mother, desperate over the illness of her two year old, left him all night in an open tomb for healing. Miriam told us how she used to loave her cooking and run off to play until her husband would find her in the street and bring her back. "Oh, these women that come to the clinic," exclaimed Dr. P., "and these little girls, the eyes that they want given back, the babies!" Talbot Kelly, Egypt's friend and "poet in colours," quotes the rite of infant mortality as ninety per cent., and adds, "One cannot, therefore, hope for much improvement in a race whose mothers, usually married far too young, are raised but little above the beasts, and possess neither the ability nor the inclination to train their children properly ... . Indeed, I cannot help feeling that the solution of the whole question lies in the education of the women." The testimony of Lord Cromer is on similar lines. The solution of Egyptian problems lies in the education and elevation of their womanhood.

This fact is brought strongly into evidence by contrasting the percentages of literates, 10.5 per cent. in the case of men, 0.3 per cent. in the case of the women. Out of 836,000 girls of school age, only 22,916 are at school. Does the reader realize what this means? For all of these girls God's Word must indeed be " ministered by us, written -with the Spirit of the living God-in tables that are hearts of flesh." Untrained minds may be pitifully unable to reason or retain, but there is often an amazing response and spiritual perception. The individual story is again the most vivid argument.

Late of an April aftemoon the girls in a little Moslem sewing-school sat on the ground in a tiny court. Their eagerness and interest were apparent as they listened for the first time to the story of Mary. Presently a tiny bit of blind humanity came up the passage between the houses, and with outstretched hands touched lightly one and 
another as she toddled toward the voice, telling of seekers for the Christ-child years ago. My heart ached as I took her cold little hands in mine and smoothed the tangled curls. "Ayesha" = life,--but what a life it must be for her! Then I asked if anyone remembered the story of Samuel that we taught on the last visit. Fateema said, "We can't. It is too long ago. Please teach us more so that we may know something "; and my heartache grew, for underneath the eager eyes were sightless lives reaching out for guidance as their faltering footsteps sought the voice.

While Zeinab was sick, the doctor found lying just above her heart a tiny silver cross, and asked in surprise why she, a Moslem, should wear the cross. "Never mind," she apologized quickly, "I'll take it off. Yes, I'm a Mohammedan, but I got it to make me well." Very tenderly he explained to her the working of the great Physician, and now she and her house are learning to pray for His healing touch.

One year every Moslem was taken from the school in $\mathrm{H}-$ with the same excuse, "She goes to her room and prays to your God. Wo cannot leave her longer." Often I think of those twenty-five girls and wonder whether still they kneel alone with outstretched bands and pray.

Twelve year old Aesma had spent seven wonderful months in school, and on her return people asked of her mother: "What is the matter with Aesma, her face shines so ?" One fateful day an uncle took her to his house to marry his son. There, in spite of all opposition and the destruction of her Bible, she remained faithful in her testimony to Christ, with the result that she was cast out with contumely and reproach. She was received back by her mother, who was drawn by the child's influence to love the Saviour also. Persecution began once more; the men of the family ate at cafés and refused the women any money for clothes or food. Every day the uncle came with taunts and offers of all comfort if she would peaceably leave her Christ. Even meetings with the missionary at a friendly Coptic house were stopped by advances from their priest. Then followed the uncle's ultimatum-marriage, Islamic teaching, change of faith. Her quiet reply, "I will not become a Muslina again if you kill mo," so enraged him that he struck and kicked her furiously. When he finally left, she poured oil on her dress and set fire to it only to be saved once more by her mother. For a while the tormentors were silenced, but the final proposal is to sell her for twenty pounds to a village bey. The mother's jewels and her own are gone ; the rent is over due ; holp will come on only one condition; but still every Sabbath finds her brave sweet face at service, and if at all possible to escape she slips daily into the little school to read and sew, "choosing rather to share ill-treatment " and " accounting the reproach of Christ greater riches than the treasures of Egypt."

A few there are like Aesma who know the voice; others who having heard from their prisons have no opportunity ever to hear again, and then there are the countless number of Ayeshas whose sigh rises from lives that cannot know of light since no faintest gleam has ever roached their souls-" no hope and without God."

The sadness of one life we may try to fathon, pexchance even of a score, but for the millions we have no plummet, innagination breaks at the thought, but we begin to know why the blood wept from the heart of our Christ on that garclen night.

Alesandria.

LORETTA A. BITTCHELL. 